\title{
The proximity of distance education
}

\section{Giovanni Paolo Caruso, Lucia Ferlino}

Institute for Educational Technologies (ITD), National Research Council (CNR), Genoa, Italy, caruso@itd.cnr.it, ferlino@itd.cnr.it

\begin{abstract}
The Institute for Educational Technologies (ITD) in Genoa, part of Italy's National Research Council (CNR) has long held high-quality on-site training and refresher courses for teachers that are recognized by Italy's Ministry of Education and Research (MIUR). In addition to participating in face-to-face initiatives, Italy's teachers are increasingly exploiting opportunities to participate in certified online training initiatives. These are especially popular as they permit teachers a high degree of autonomy and flexibility in managing their learning. Since September 2014, ITD-CNR has been testing and implementing innovative training methods (mostly on behalf of a large Italian public research organization). These include webinars, which make it possible to reach large numbers of participants. ITD-CNR has also designed and made available a series of open courses designed to help teachers develop the skills needed to enhance classroom integration of students with disabilities, specific learning disabilities, and other special educational needs. These courses also address the use of technologies and strategies for more effective school inclusion. To ensure these training proposals remain usable over time and continue to provide relevant content, in 2016 ITD-CNR created an online platform called Essediquadro Training (https://sd2.itd.cnr.it/corsiformazione). This aggregates and makes available five open courses that are free of charge, totalling 130 hours of high-quality, certified training.In the past two years, the platform has attracted over 9000 registered users (pre-and in-service teachers), and has become a focal point for similar training initiatives launched by schools and universities, who are integrating their own training courses with those on offer from Essediquadro Training. In this contribution, we illustrate the characteristics and contents of the Essediquadro Training platform, examine the use of webinars for teacher training, and offer some considerations based on results of satisfaction questionnaires compiled by platform users.
\end{abstract}

Keywords: Distance education, Open education, E-learning \& experiences 


\section{Introduction}

The Institute for Educational Technologies (ITD) in Genoa, part of Italy's National Research Council (CNR), has long held high-quality on-site training and refresher courses for teachers. ITD is a public research organization and its courses are recognized by Italy's Ministry of Education and Research (MIUR). In addition to participating in face-to-face initiatives, Italy's teachers are increasingly exploiting opportunities to participate in certified online training initiatives. These are especially popular as they permit teachers a high degree of autonomy and flexibility in managing their learning [Borg, 2015; Fitzpatrick, 2012; Johnson \& Aragon, 2003; McCombs, 2015; Miyazoe \& Anderson, 2015; Zoumenou et al., 2015]. Since September 2014, ITD-CNR has been testing the use of webinars as an innovative training tool capable of reaching large numbers of participants.

For several years now interest has been growing in the adoption of this social and interactive mode of communication within a wide range of educational contexts, including teacher training [Borg, 2015; Fitzpatrick, 2012; Johnson \& Aragon, 2003; McCombs, 2015; Miyazoe \& Anderson, 2015; Zoumenou et al., 2015]. Universities, publishing houses, research organizations, and recently even schools have begun to offer webinars addressing various topics. These may be one-off events or part of structured training paths, and may or may not involve payment of a registration fee. In some cases participants need to register or lodge a membership application in order to obtain a certificate of attendance.

The design of that initiative calls for inclusion of a test to validate participant learning. Evaluation of the webinar's efficacy can be achieved by submitting a questionnaire to participants and analysing their feedback [Gharis et al., 2014; Zoumenou et al., 2015].

To ensure these training proposals remain usable over time and continue to provide relevant content, in 2016 ITD-CNR, the webinar recordings and support materials have been made available on Essediquadro Training (https://sd2.itd.cnr.it/corsiformazione), an online platform, in the form of structured courses that teachers can follow in self-guided mode as a supplement to the regular training they receive from their school.

This paper presents an analysis and a comparison of questionnaire data collected from participants attending teacher training webinars and the courses in Essediquadro Training platform.

\section{Teacher training webinars}

Back in 2014, the authors faced the challenge of designing and deploying an innovative training initiative centred on adoption of what then (in Italy at least) a largely unknown tool, the webinar. The initiative sought to address the real training needs of teachers 
regarding: digital technologies (of the low cost and open variety) and inclusion. These needs emerged from meetings with teachers in schools and from online forums. Meeting such training needs through face to face interventions often proves difficult for organisational and logistical reasons, placing severe limits on potential coverage. The steady increase in teachers' use of online resources and services like email, whether on computer or via mobile devices, is opening up new training scenarios that leverage the added value of e-learning.

Hence the primary aim was to reach out and engage potential users in sessions that, for most of them, represented a new and innovative way of participating in professional training. The secondary aim was to propose content presented by experts who combine solid know-how and expertise with communicative capacity and a passion for their work.

The first cycle of 25 webinars (50 hours, from September 2014 to March 2015) was entitled "Technologies and Inclusion". This constituted a substantial set of training opportunities on a variety of topics such as inclusion, special educational needs (SEN) and specific learning disabilities. These were well received in terms of coverage and quality (presenter expertise) but also in terms of access, given that geographical, temporal, economic and organisational constraints often prevent people from participating in professional training initiatives. Users expressed their appreciation of these online training experiences even before completing the questionnaire. This immediate positive response encouraged the launch other training initiatives organised in collaboration with ITD. Subsequently, four further webinar cycles were held from February 2015 to December 2017 on the following topics: (a) "If I do something, I understand, but if I understand, I can do even better" (16 hours); (b) "Formally, training the mind freely" (30 hours); (c) "Specific Learning Disabilities: you never stop learning" (14 hours); (d) "Inclusion: the value of difference" (20 hours).

These courses were designed to develop teacher competencies in supporting classroom integration of learners with disabilities and other SEN, in using digital technologies to optimize integration. For each webinar cycle, participant feedback was collected via an evaluation questionnaire.

\section{Evaluation of teacher training webinars}

As mentioned above an anonymous evaluation questionnaire was submitted to participants (3903 registered users; 938 users that completed the surveys) in an effort to gain insights into the potential and limitations of webinars as a training tool (for details, see Table 1).

More specifically, the questionnaire was designed to (a) survey approval levels and critical aspects of the proposals, and (b) collect suggestions for optimizing the training experience. 


\subsection{Tool and procedure}

The questionnaire was created with Surveygizmo (https://app.surveygizmo.com/), a tool that had already been used by ITD and which was chosen for its accessibility characteristics. The questionnaire comprised 33 questions: some of these were included to gather socio-demographic data (gender, age range, geographical location, teacher category), while others were designed to obtain quantitative and qualitative evaluation data on the webinars themselves; others still had the purpose of collecting participants' opinions regarding the perceived quality of the webinars as a training tool.

Questions devoted to qualitative evaluation of the webinars posed a set of descriptors (e.g., understandable, easy to follow, stimulating, practical, theoretical, simple, applicable, useful, up-to-date contents) graded according to a four-point Likert scale (from "not at all" 1 point to "very much" 4 points). The questions formulated to collect opinions about the perceived quality of the deployed webinars focused on aspects like the communicative effectiveness and competence of the speaker and the quality of the support materials. Once again these were graded on a four-point Likert scale from "poor" (1 point) to "excellent" (4 points).

\subsection{Analysis of results}

Data analysis is reported in the following sub-sections: (a) socio-demographic data for participant profiling; (b) some data about the webinars followed by teachers; (c) qualitative evaluationof the webinars; (d) opinions about the webinar as a training tool.

\subsubsection{Socio-demographic information}

The first section of the questionnaire was devoted to socio-demographic information.

Samples of the five cycles of webinar participant populations reveal a majority of women attending (from $81.9 \%$ to $93.7 \%$ ). This finding is in line with general profile of the Italy's teacher population (84.8\%) figured by OECD [OECD, 2017]. The prevalent age range was between 50-59 years old, with a percentage ranging from $38 \%$ to $50 \%$. OECD figures for Italy's teacher population aged $50+$ are $57 \%$ for primary school, $73 \%$ for upper secondary school, and $51 \%$ for tertiary education). These are the highest percentages among OECD countries [OECD, 2017]. Regarding geographic location, a majority of participants reside in the north of the country, with percentages ranging from $56.6 \%$ to $86.4 \%$. Data on education role covered reveal that, in the samples, mainstream teachers were in the majority (from $46.7 \%$ to $67.1 \%$ ). This result is reassuring because the topics dealt with in the courses are often considered important only to special education teachers (for details, see Table 2). 


\subsubsection{Data on webinar participation}

Questions in the second section of the survey were devoted to investigating why and how participants followed the webinars, as well as the efficacy of the tools used (complete data are reported in Table 3). Training/professional development was the chief reason given for all five samples (from $76.6 \%$ to $86.1 \%$ ). Participants indicated that they found the slide presentation and the voice of the speaker to be the most effective tools.

\subsubsection{Qualitative evaluation of the webinars}

The questions in the third section were designed to obtain information for qualitative evaluation of the webinars.

Overall, results indicate that the webinars were evaluated positively: they were considered understandable (highly or fairly), while the vast majority found them easy to follow, with up-to-date contents, useful and simple (complete data are reported in Table 4) The majority of users found the webinars met or exceeded their general expectations (adequate expectations: from $63 \%$ to $71.9 \%$; higher expectations: from $22.2 \%$ to $31.9 \%$; for details, see Table 5). Users also evaluated the effectiveness of training. Knowledge/competence increased "fairly" for many, from $68.1 \%$ to $75 \%$, and "highly" for others from $23.6 \%$ to $26 \%$ (for details, see Table 6). Other aspects of the webinars that were investigated include the communicative effectiveness of the speaker, competence regarding content area, and the quality of the materials offered (slides, videos, etc.). Participants rated all three aspects as "excellent" or "good", with speaker competence receiving particularly high scores.

The questionnaire also provided the opportunity to provide personal comments. The most frequently mentioned positive aspects were the clarity and competence of the speakers, their practical suggestions, the wide range of topics covered, the novel mode of interaction, being able to follow from home or wherever.

\subsubsection{Webinar as training tool}

The questions in the fourth section had the aim to collect opinions about the webinar as training tool, in particular evaluating its being effective, fun, engaging, flexible with a scale from "not at all" to "a lot". More relevant data referred to the efficacy (a lot and enough) and to the flexibility (a lot and enough), characteristics highlighted by over $95 \%$.

\section{From webinars to the platform}

Since 2016, the webinar recordings and support materials have been made available on ITD's Essediquadro Training Moodle platform in the form of structured courses that teachers can follow in self-guided mode as a supplement to the regular training they receive from their school. The platform was created to provide an ongoing stream of training 
initiatives, to gather related learning contents, and to track user activity. The webinar-based courses the site offers meet a variety of training needs, including those of teachers following training courses organized by their own schools or pursuing further studies on a personal basis.

\subsection{The Essediquadro training platform}

The online learning space is simple and essential in structure. A menu provides access to the range of courses on offer, which are available either on an open access basis or reserved to registered users.

\subsubsection{The courses}

As mentioned above, Essediquadro's courses bring together the contents of the webinar cycles run wholly or jointly by ITD. The webinar recordings and related learning materials were subsequently repurposed into online courses that could be accessed in always-on mode, thus providing training opportunities for a much broader cohort of teachers.

All the courses have the same structure. Each comprises a course presentation and a certain number of learning modules. The modules each contain: (a) a recorded webinar; (b) the slides and/or other materials distributed during the webinar; (c) a set of multiple choice comprehension quizzes based on the webinar contents. Trainees who successfully complete all of the module quizzes can download a course certificate specifying the number of training hours completed.

In addition to the courses developed by ITD, the platform also features a number of other ministry-approved courses run by individual schools under ITD supervision.

\subsubsection{Supplementary spaces}

The platform also has (a) a space for users to share views and information about the online training courses, congresses and seminars they've attended, and other events of interest, and (b) a FAQ section providing guidance on a number of course-related issues, such as how the content is delivered, how to follow the courses, and their validity status.

\subsection{Platform use: some data}

Since the platform was launched in January 2016, over 9300 users have registered (May 2018). Initially, knowledge about the Essediquadro Training courses spread largely through word of mouth. However, as of September 2017, they have been listed in Sofia, the Ministry of Education's online catalogue of officially accredited training initiatives run by schools and training providers. This has considerably amplified access to the courses, with 
numbers tripling in just a few months. There is a general tendency for users to enrol in more than one course, with 2634 users enrolled in 2 courses, 738 in 3 courses, 793 in 4 courses, etc.

\subsection{Evaluation of the training courses}

Evaluation has been carried out to gain insight into the nature of the trainee population that uses the platform, the degree of user satisfaction, and perceived strengths and weaknesses. To this purpose, an anonymous evaluation survey has been proposed for each courses (for details, see Table 7).

\subsubsection{Tool and procedure}

The means chosen for conducting the evaluation was Moodle's native questionnaire tool. The questionnaire itself comprises 23 questions, some for gathering socio-demographic data (gender, age range, geographical location, teacher category) and others for obtaining quantitative and qualitative evaluation data specifically about the webinars.

Questions devoted to qualitative evaluation of the webinars posed a set of descriptors (e.g., understandable, easy to follow, stimulating, practical, theoretical, simple, applicable, useful, up-to-date contents) graded according to a five-point Likert scale (from "very little" 1 point to "very much" 5 points).

\subsubsection{Analysis of results}

Data analysis is reported in the following sub-sections: (a) socio-demographic data for participant profiling; (b) some data about the Essediquadro courses teachers followed; (c) qualitative evaluation of the Essediquadro courses.

\subsubsection{Socio-demographic data}

The first section of the questionnaire was devoted to socio-demographic information, namely gender, age, geographical location, role covered in school (for details, see Table 8). Samples of the five cycles of webinar participant populations reveal a majority of women attending (from $83 \%$ to $87 \%$ ). This finding is in line with the general profile of Italy's teacher population $(84.8 \%$ ) as measured by the OECD [OECD, 2017]. The prevalent age range was between 50-59 years old, with a percentage ranging from $36 \%$ to $42 \%$. This finding is also in line with OECD figures for Italy's teacher population [OECD, 2017] whereby teachers aged $50+$ comprise $57 \%$ of the teaching workforce at primary school, $73 \%$ at upper secondary school, and $51 \%$ in tertiary education. These are the highest percentages for the 50+ age bracket among OECD countries [OECD, 2017]. Regarding geographic location, a majority of participants reside in the south of the country, with 
percentages ranging from $50 \%$ to $65 \%$. Data on teacher category reveal that, in the samples, mainstream curriculum teachers were in the majority.

\subsubsection{Some data on the courses}

A specific section of the survey was devoted to investigating the mode of participation, with questions designed to gauge where participants followed the courses and what devices they used to do so. Participants mainly followed the courses from home from $93 \%$ to $96 \%$, using fixed devices from $70 \%$ to $72 \%$ (complete data are reported in Table 9 ).

\subsubsection{Qualitative evaluation of the courses}

Another set of questions was devoted to collecting information for qualitative evaluation of the courses. Results indicate that the courses are evaluated positively: asked whether the courses were understandable, easy to follow, with up-to-date contents, useful and simple, the majority of users (from 96\% to 98\%) rated them "fairly" to "highly" (for details, see Table 10) Evaluation of the course speakers/experts was also positive: participants rated their competence as high from $73 \%$ to $79 \%$ and acceptable from $21 \%$ to $27 \%$, their communication as effective from $72 \%$ to $75 \%$ and involving from $24 \%$ to $27 \%$ (for details, see Table 11). For the majority of the participants: (a) the courses responded to their overall expectations (from $86 \%$ to $90 \%$ ); (b) the established goals were achieved (from $84 \%$ to $88 \%$ ); (c) the course will impact on their teaching practice (from $68 \%$ to $74 \%$ ); (d) the courses can be recommended to colleagues, especially in the case of mainstream curriculum teachers (for details, see Table 12) Another section of the questionnaire investigated teachers' motives for following the courses. The collected data indicate that for the majority of participants the courses on offer: (a) dealt with topics not covered in their school's threeyear training plan (from $66 \%$ to $71 \%$ ); (b) are in line with the priorities established in their school's official policy and planning documents (from 51\% to 53\%); (c) were freely chosen (from $81 \%$ to $84 \%$ ); (d) formed part of their additional training quote above the commitments envisaged by the school's Development Plan (from 74\% to 77\%); (e) became known through word of mouth (from $40 \%$ to $49 \%$ ) (for details, see Table 13). In addition, participants were also asked to rate the usability of the platform. The majority (from $94 \%$ to 95\%) considered it easy to use (for details, see Table 14).

The questionnaire also gave participants the opportunity to make personal comments and suggestions. As well as expressing their appreciation of the professionalism of the speakers, the quality of the contents, and the method of course delivery, the participants also stressed the perceived usefulness and applicability of what they had learned to the daily teaching practice. 


\section{Comparing data}

Comparing the survey findings regarding the teacher training offered via webinar with that on the online platform, a number of general observations can be made.

In both cases, the predominate participant profile is that of a female mainstream curriculum teacher aged between 40 and 60 years old who followed the training from home. The online courses available in always-on mode were easy to access, making them particularly popular among female teachers, as they made it possible to reconcile family and work commitments. This was highlighted in the open comment made by a number of respondents ("I don't have to move from home", "Saving time and money", "I can't attend conferences and courses with the family", "I can also follow them while doing other things"). Motivation to engage in training seems to be greater in teachers who already have some experience. This may derive from the increasing variety and number of learner disorders, difficulties and disabilities in schools in recent years. In addition, teachers may recognize the need for professional growth by broadening and updating the (often scant) initial training they received long ago, especially in areas in which their knowledge and knowhow is relatively weak.

While the two types of training proposal featured essentially the same contents (live and recorded webinars), they addressed two different cohorts of users. In both cases, a positive user evaluation emerged. The webinars were considered understandable, easy to follow and useful; the contents were held to be up to date, and the webinar speakers effective and competent. The courses met expectations, helping participants to reach the set goals; registered users tended to follow more than one course. The participants stated that the training would impact on their teaching practice and that they would advise colleagues to take part.

\section{Conclusion and future prospects}

This paper has reported the evaluation of an online teacher training programme proposed by CNR-ITD centred on webinars. The initiative was launched in 2014 when webinars were relatively uncommon in teacher training in Italy, and therefore represented an innovative approach for the majority of participants. It immediately became clear that they were a big success.

The participants expressed enthusiasm for the way that this readily accessible training mode allowed them to follow quality training from home, if need be via the always-on webinar recordings. These also represented valuable resources for use in school-based training activities involving colleagues. The innovative nature of this training initiative meant that it was somewhat risky proposition. Participant acceptance was by no means guaranteed but 
the initial positive results are highly encouraging and bolster determination to continue the challenge. The analysis of the data confirms that teacher training can be performed in an innovative fashion through employment of effective and flexible digital tools. An added value of this initiative was that the materials produced during the training webinars (webinar recordings, slides, quizzes and certificates) could be repurposed into actual courses (described in the second part of the contribution). These were made available on the Essediquadro Training platform, thus enriching the range of CNR-ITD's teacher training proposals. The steady increase in the number of registered users and guests on the platform is testament to the quality of these open courses and to the credibility of CNR-ITD as a provider of training programmes that teachers can follow in their own time, with the possibility of obtaining officially recognized certification. Essediquadro Training has become a reference point for schools and universities, who have adopted the courses as part of the quota of online teacher training they offer. A decisive factor in promoting the growth of the service, beyond word of mouth, was the inclusion of the courses in Sofia, the Ministry of Education's online catalogue of officially recognised training initiatives. Finally, the platform's considerable ease of use (confirmed by almost all its registered users) is another element contributing to its success. It requires no specific technical skills and so can be used by a large number of users.

In the past two years, the platform has attracted over 9000 registered users (pre- and inservice teachers), and has become a focal point for similar training initiatives launched by schools and universities, who are integrating their own training courses with those on offer from Essediquadro Training.

So how can the service be improved going forward?

The webinars could be enhanced by introducing greater interactivity: the speakers sometimes complained about not being able to see their audience and some participants wished to have more time to ask questions. As to the Essediquadro Training platform in general, in addition to providing new courses, we would like to implement functions for creating personalized training paths capable of meeting the training needs of individual teachers and lending distance training a stronger sense of proximity.

Summing up, the road taken appear to be the right one and, with the necessary adjustments, is worth following in the future.

\section{Acknowledgements}

A special thanks to Sabrina Panesi and Jeffrey Earp for linguistic revision. 


\section{References}

Borg S (2015). The benefits of attending ELT conferences. ELT Journal 69/1: 35-46.

Fitzpatrick, T. (2012) Key Success Factors of eLearning in Education: A Professional Development Model to Evaluate and Support eLearning, US-China Education Review A 9 (2012) 789-795.

Gharis L, Bardon RE, Hubbard W, Taylor E, Gonzalez-Jeuck G (2014). Using Survey Responses to Determine the Value-Added Features of a Webinar Portal System for Adoption by Natural Resource Professionals, Journal of Extension, v52 n6 Article 6RIB4 Dec 2014.

Johnson, S.D. \& Aragon, S.R. (2003). An Instructional Strategy Framework for Online Learning Environments. New Directions for Adult and Continuing Education, 100, 31-43.

McCombs, B. (2015). Learner-Centered Online Instruction. New Directions for Teaching and Learning, 2015(144), 57-71.

Miyazoe, T., \& Anderson, T. (2015). Interaction equivalency in an OER, MOOC and informal learning era. Best of Eden 2013 Issue - EURODL 2013 Issue.

OECD (2017) Education at a Glance 2017: OECD Indicators, OECD Publishing, Paris.

Zoumenou V, Sigman-Grant M, Coleman G, Malekian F, Zee JMK, Fountain BJ, Marsh A (2015). Identifying Best Practices for an Interactive Webinar, Journal of Family and Consumer Sciences, v107 n2 p62-69 2015. 
Table 1. Attendance of live and recorded webinars

\begin{tabular}{ccccc}
\hline $\begin{array}{c}\# \\
\text { Registered } \\
\text { participants }\end{array}$ & $\begin{array}{c}\text { Average } \\
\text { live } \\
\text { attendance }\end{array}$ & $\begin{array}{c}\text { \# YouTube } \\
\text { channel } \\
\text { followers }\end{array}$ & $\begin{array}{c}\# \\
\text { YouTube channel } \\
\text { views }\end{array}$ & $\begin{array}{c}\# \text { attendance } \\
\text { certificates } \\
\text { issued }\end{array}$ \\
\hline 508 & 78 & $\begin{array}{c}463 \\
(09 / 14-05 / 18)\end{array}$ & $\begin{array}{c}55814 \\
(09 / 14-05 / 18)\end{array}$ & $\begin{array}{c}2318 \\
(09 / 14-01 / 16)\end{array}$ \\
\hline
\end{tabular}

\begin{tabular}{|c|c|c|c|c|c|}
\hline $\begin{array}{l}\text { Technologies and } \\
\text { inclusion }\end{array}$ & 508 & 78 & $\begin{array}{c}463 \\
(09 / 14-05 / 18)\end{array}$ & $\begin{array}{c}55814 \\
(09 / 14-05 / 18)\end{array}$ & $\begin{array}{c}2318 \\
(09 / 14-01 / 16)\end{array}$ \\
\hline $\begin{array}{l}\text { If I do something, I } \\
\text { understand ... }\end{array}$ & 580 & 185 & & & 2379 \\
\hline $\begin{array}{l}\text { Formally, training the } \\
\text { mind freely }\end{array}$ & 676 & 175 & $\begin{array}{c}654 \\
(02 / 15-05 / 18)\end{array}$ & $\begin{array}{c}71366 \\
(02 / 15-05 / 18)\end{array}$ & $(02 / 15-01 / 16)$ \\
\hline $\begin{array}{l}\text { Inclusion: the value of } \\
\text { the difference }\end{array}$ & 865 & 261 & & & N/A \\
\hline $\begin{array}{l}\text { Specific Learning } \\
\text { Disabilities: you never } \\
\text { stop learning }\end{array}$ & 1174 & 368 & $\begin{array}{c}442 \\
(10 / 15-05 / 18)\end{array}$ & $\begin{array}{c}41134 \\
(10 / 15-05 / 18)\end{array}$ & N/A \\
\hline
\end{tabular}

Table 2. Number of registered users and of returned and completed questionnaires

\begin{tabular}{lccc} 
& \# registered users & \# returned quest. & \# completed quest. \\
\hline Technologies and inclusion & 508 & 199 & 138 \\
\hline If I do, I understand ... & 580 & 239 & 184 \\
\hline Formally, training the mind freely & 676 & 193 & 158 \\
\hline Specific Learning Disabilities & 1174 & 306 & 262 \\
\hline Inclusion: the value of difference & 865 & 224 & 196 \\
\hline
\end{tabular}


Table 3. Socio-demographic variables

\begin{tabular}{|c|c|c|c|c|c|c|c|c|c|c|c|}
\hline & & \multicolumn{2}{|c|}{$\begin{array}{l}\text { Technologies and } \\
\text { inclusion }\end{array}$} & \multicolumn{2}{|c|}{$\begin{array}{c}\text { If I do, I understand, } \\
\text { but if I understand } \\
{[\ldots]}\end{array}$} & \multicolumn{2}{|c|}{$\begin{array}{l}\text { Formally, training } \\
\text { the mind freely }\end{array}$} & \multicolumn{2}{|c|}{$\begin{array}{l}\text { Specific Learning } \\
\text { Disabilities: you } \\
\text { never stop learning }\end{array}$} & \multicolumn{2}{|c|}{$\begin{array}{l}\text { Inclusion: the value } \\
\text { of the difference }\end{array}$} \\
\hline & & \# & $\%$ & \# & $\%$ & \# & $\%$ & \# & $\%$ & \# & $\%$ \\
\hline \multirow{2}{*}{ Gender } & Male & 25 & 18.1 & 19 & 10.3 & 10 & 6.3 & 25 & 9.5 & 26 & 13.3 \\
\hline & Female & 113 & 81.9 & 165 & 89.7 & 148 & 93.7 & 237 & 90.5 & 170 & 86.7 \\
\hline \multirow{5}{*}{ Age } & $20-29$ & 2 & 1.4 & 7 & 3.8 & 3 & 1.9 & 4 & 1.5 & 4 & 2 \\
\hline & $30-39$ & 10 & 7.2 & 23 & 12.5 & 14 & 8.9 & 31 & 11.8 & 16 & 8.2 \\
\hline & $40-49$ & 50 & 36.2 & 75 & 40.8 & 57 & 36.1 & 98 & 37.4 & 61 & 31.1 \\
\hline & $50-59$ & 69 & 50 & 70 & 38 & 69 & 43.7 & 121 & 46.2 & 97 & 49.5 \\
\hline & +60 & 7 & 5.1 & 9 & 4.9 & 15 & 9.5 & 8 & 3.1 & 18 & 9.2 \\
\hline \multirow{3}{*}{$\begin{array}{l}\text { Geographic } \\
\text { area }\end{array}$} & North & 90 & 65.2 & 159 & 86.4 & 119 & 75.3 & 186 & 71.0 & 111 & 56.6 \\
\hline & Centre & 26 & 18.8 & 11 & 6.0 & 23 & 14.6 & 54 & 20.6 & 22 & 11.2 \\
\hline & South & 22 & 15.9 & 14 & 7.6 & 16 & 10.1 & 22 & 8.4 & 63 & 32.1 \\
\hline \multirow{3}{*}{ Role } & $\begin{array}{l}\text { Subject } \\
\text { matter } \\
\text { teacher }\end{array}$ & 66 & 47.8 & 86 & 46.7 & 106 & 67.1 & 155 & 59.2 & 101 & 51.5 \\
\hline & $\begin{array}{l}\text { Special } \\
\text { educatio } \\
\mathrm{n} \text { teacher }\end{array}$ & 51 & 37 & 79 & 42.9 & 43 & 27.2 & 66 & 25.2 & 85 & 43.4 \\
\hline & Other & 21 & 15.2 & 19 & 10.3 & 9 & 5.7 & 41 & 15.7 & 10 & 5.1 \\
\hline \multirow{2}{*}{$\begin{array}{l}\text { CTS } \\
\text { operator }\end{array}$} & YES & 30 & 21.7 & 10 & 5.4 & 13 & 8.2 & 12 & 4.6 & 13 & 6.6 \\
\hline & $\mathrm{NO}$ & 108 & 78.3 & 174 & 94.6 & 145 & 91.8 & 250 & 95.4 & 183 & 93.4 \\
\hline
\end{tabular}


Table 4. Data on webinar participation

\begin{tabular}{|c|c|c|c|c|}
\hline $\begin{array}{l}\text { Technologies } \\
\text { and inclusion }\end{array}$ & $\begin{array}{l}\text { If I do, I } \\
\text { understand, but } \\
\text { if I understand } \\
{[\ldots]}\end{array}$ & $\begin{array}{l}\text { Formally, } \\
\text { training the mind } \\
\text { freely }\end{array}$ & $\begin{array}{l}\text { Specific } \\
\text { Learning } \\
\text { Disabilities: you } \\
\text { never stop } \\
\text { learning }\end{array}$ & $\begin{array}{l}\text { Inclusion: the value } \\
\text { of the difference }\end{array}$ \\
\hline ' & $\%$ & \# & $\%$ & $\%$ \\
\hline
\end{tabular}

\begin{tabular}{|c|c|c|c|c|c|c|c|c|c|c|c|}
\hline $\begin{array}{l}\text { Reasons for } \\
\text { participation }\end{array}$ & $\begin{array}{l}\text { Personal } \\
\text { deepening } \\
\text { Training/ } \\
\text { professional } \\
\text { development }\end{array}$ & 11 & 9.6 & 141 & 23.4 & 136 & 13.9 & 205 & 21.8 & 34 & 17.3 \\
\hline \multirow{3}{*}{ Usable } & Live & 4 & 9.1 & 112 & 60.9 & 75 & 47.5 & 183 & 71.2 & 103 & 52.6 \\
\hline & Deferred & 9 & 8.8 & 33 & 17.9 & 39 & 24.7 & 26 & 10.1 & 26 & 13.3 \\
\hline & $\begin{array}{l}\text { Live and } \\
\text { deferred }\end{array}$ & 5 & 2.6 & 39 & 21.2 & 44 & 27.9 & 48 & 18.7 & 67 & 34.2 \\
\hline \multirow{5}{*}{$\begin{array}{l}\text { Effectiveness } \\
\text { tools }\end{array}$} & $\begin{array}{l}\text { Slide } \\
\text { presentation }\end{array}$ & 15 & 3.3 & 150 & 81.5 & 124 & 78.5 & 203 & 77.5 & 157 & 80.1 \\
\hline & Chat & 4 & 4.6 & 45 & 24.5 & 25 & 15.8 & 47 & 17.9 & 32 & 16.3 \\
\hline & Speaker voice & 1 & 5.9 & 124 & 67.4 & 83 & 52.5 & 141 & 53.8 & 96 & 49 \\
\hline & Speaker video & 1 & 7.0 & 33 & 17.9 & 44 & 27.9 & 75 & 28.6 & 59 & 30.1 \\
\hline & $\begin{array}{l}\text { Connected } \\
\text { video }\end{array}$ & 5 & 7.1 & 72 & 39.1 & 86 & 54.4 & 126 & 48.1 & 94 & 48 \\
\hline
\end{tabular}


Table 5 Evaluation of the webinars $(\mathrm{H}=$ highly, $\mathrm{F}=$ fairly, $\mathrm{L}=$ little, $\mathrm{N}=$ Not at all $)$

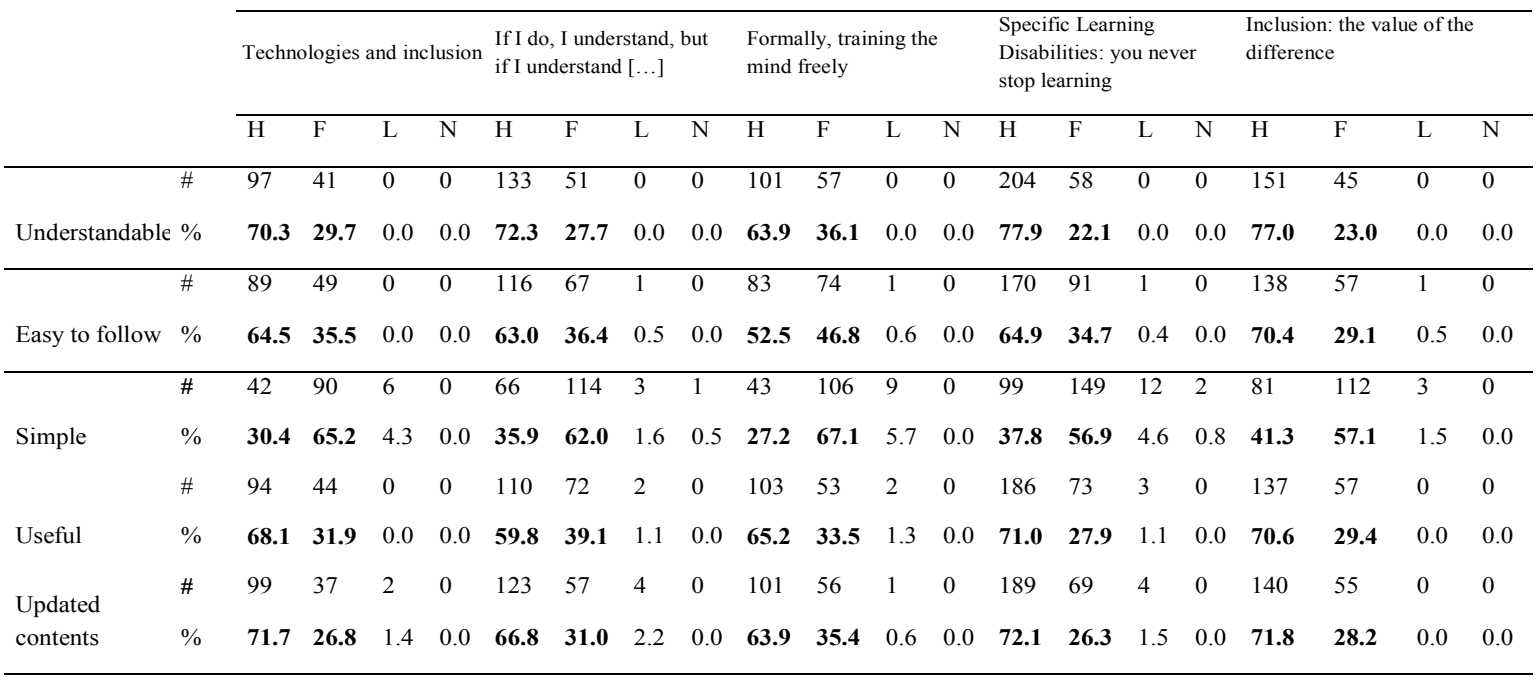

Table 6 Expectations of webinars

\begin{tabular}{|c|c|c|c|c|c|c|c|c|c|c|}
\hline & \multicolumn{2}{|c|}{$\begin{array}{l}\text { Technologies and } \\
\text { inclusion }\end{array}$} & \multicolumn{2}{|c|}{$\begin{array}{l}\text { If I do, I understand, but } \\
\text { if I understand }[\ldots]\end{array}$} & \multicolumn{2}{|c|}{$\begin{array}{l}\text { Formally, training the } \\
\text { mind freely }\end{array}$} & \multicolumn{2}{|c|}{$\begin{array}{l}\text { Specific Learning } \\
\text { Disabilities: you never } \\
\text { stop learning }\end{array}$} & \multicolumn{2}{|c|}{$\begin{array}{l}\text { Inclusion: the value of the } \\
\text { difference }\end{array}$} \\
\hline & $\#$ & $\%$ & \# & $\%$ & $\#$ & $\%$ & \# & $\%$ & $\#$ & $\%$ \\
\hline Very lower & 1 & 0.7 & 2 & 1.1 & 0 & 0 & 0 & 0 & 0 & 0 \\
\hline Lower & 0 & 0 & 7 & 3.8 & 4 & 2.5 & 3 & 1.2 & 0 & 0 \\
\hline Adequate & 87 & 63 & 128 & 69.6 & 111 & 70.3 & 167 & 63.7 & 141 & 71.9 \\
\hline Higher & 44 & 31.9 & 41 & 22.3 & 35 & 22.2 & 80 & 30.5 & 49 & 25 \\
\hline Much higher & 6 & 4.4 & 6 & 3.3 & 8 & 5.1 & 12 & 4.6 & 6 & 3.1 \\
\hline
\end{tabular}


Table 7 Knowledge/competence increase $(\mathrm{H}=$ highly, $\mathrm{F}=$ fairly, $\mathrm{L}=$ Little, $\mathrm{N}=$ Not at all $)$

\begin{tabular}{|c|c|c|c|c|c|c|c|c|c|c|c|c|c|c|c|c|}
\hline \multirow[t]{2}{*}{$\begin{array}{l}\text { Technologies } \\
\text { and inclusion }\end{array}$} & \multicolumn{4}{|c|}{$\begin{array}{l}\text { If I do, I understand, } \\
\text { but if I understand }[\ldots]\end{array}$} & \multicolumn{4}{|c|}{$\begin{array}{l}\text { Formally, training the } \\
\text { mind freely }\end{array}$} & \multicolumn{4}{|c|}{$\begin{array}{l}\text { Specific Learning } \\
\text { Disabilities: you } \\
\text { never stop learning }\end{array}$} & \multicolumn{4}{|c|}{$\begin{array}{l}\text { Inclusion: the value of } \\
\text { the difference }\end{array}$} \\
\hline & $\mathrm{H}$ & $F$ & $\mathrm{~L}$ & $\mathrm{~N}$ & $\mathrm{H}$ & $\mathrm{F}$ & $\mathrm{L}$ & $\mathrm{N}$ & $\mathrm{H}$ & $\mathrm{F}$ & $\mathrm{L}$ & $\mathrm{N}$ & $\mathrm{H}$ & $\mathrm{F}$ & $\mathrm{L}$ & $\bar{N}$ \\
\hline $\begin{array}{l}\text { Question } \\
\text { not }\end{array}$ & 43 & 124 & 15 & 0 & 40 & 112 & 6 & 0 & 68 & 179 & 15 & 0 & 48 & 147 & 1 & 0 \\
\hline expected & 23.6 & 68.1 & 8.2 & 0 & 25.3 & 70.9 & 3.8 & 0 & 26 & 68.3 & 5.7 & 0 & 24.5 & 75 & 0.5 & 0 \\
\hline
\end{tabular}

Table 8 Users' number

\begin{tabular}{lc}
$\frac{\begin{array}{c}\text { \# Registered } \\
\text { users }\end{array}}{}$ & 3401 \\
\hline Technologies and inclusion & 2820 \\
\hline Formally, training the mind freely & 2289 \\
\hline Specific Learning Disabilities & 2868 \\
\hline Inclusion: the value of difference & 2960 \\
\hline
\end{tabular}

Table 9. Number of registered users, number of questionnaires

\begin{tabular}{lcc}
\cline { 2 - 2 } & $\begin{array}{c}\text { \# Registered\# Questionnaires } \\
\text { users }\end{array}$ \\
\hline Technologies and inclusion & 3401 & 666 \\
\hline If I do, I understand ... & 2820 & 572 \\
\hline Formally, training the mind freely & 2289 & 530 \\
\hline Specific Learning Disabilities & 2868 & 566 \\
\hline Inclusion: the value of difference & 2960 & 747 \\
\hline
\end{tabular}


Table 10. Socio-demographic variables

\begin{tabular}{|c|c|c|c|c|}
\hline $\begin{array}{l}\text { Technologies and } \\
\text { inclusion }\end{array}$ & $\begin{array}{c}\text { If I do, I } \\
\text { understand, but if } \\
\text { I understand }[. . .]\end{array}$ & $\begin{array}{l}\text { Formally, training } \\
\text { the mind freely }\end{array}$ & $\begin{array}{c}\text { Specific Learning } \\
\text { Disabilities: you } \\
\text { never stop } \\
\text { learning }\end{array}$ & $\begin{array}{c}\text { Inclusion: the } \\
\text { value of the } \\
\text { difference }\end{array}$ \\
\hline
\end{tabular}

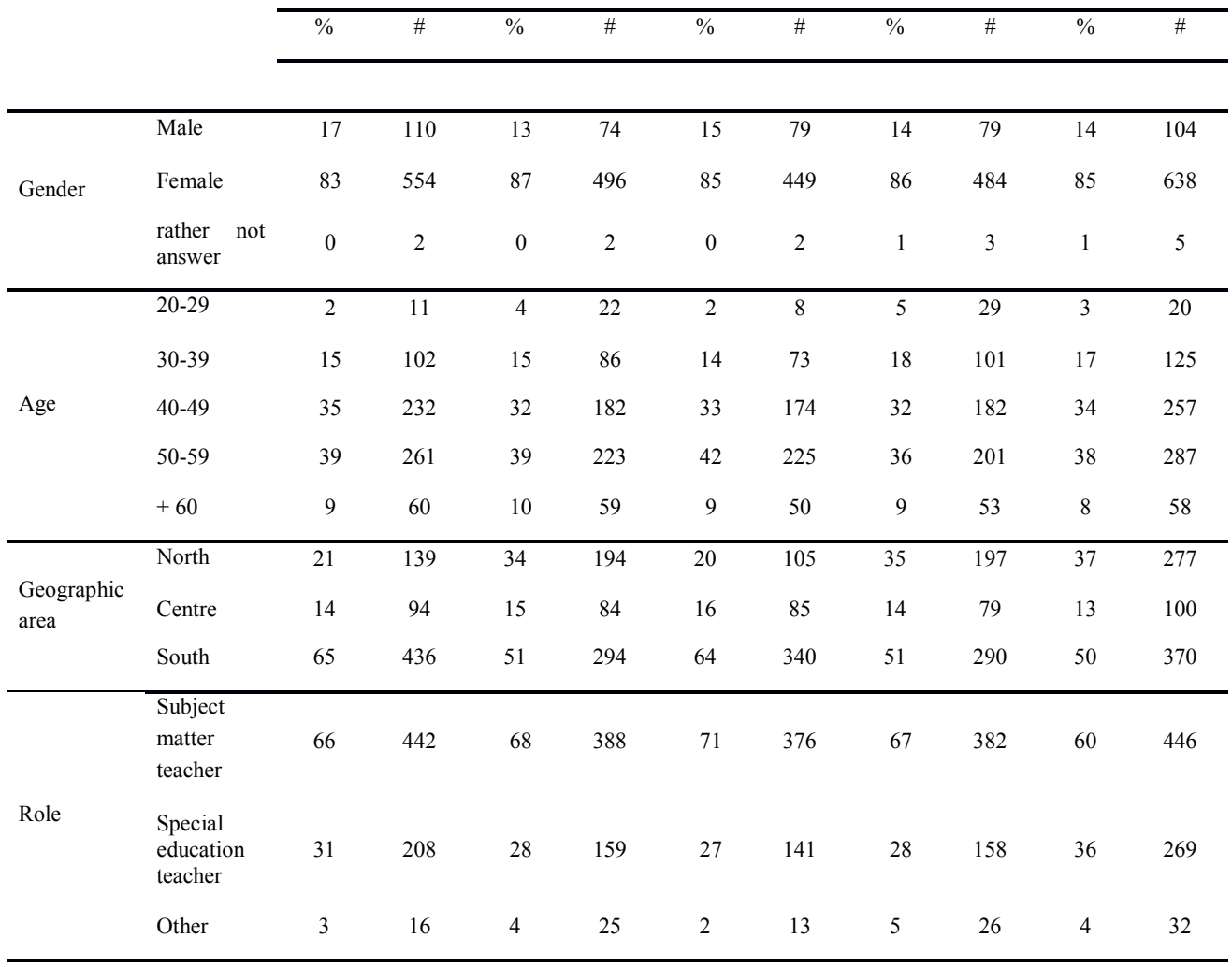


Table 11. Some data about mode of participation in the courses.

\begin{tabular}{|c|c|c|c|c|c|c|c|c|c|c|}
\hline & \multicolumn{2}{|c|}{$\begin{array}{c}\text { Technologies and } \\
\text { inclusion }\end{array}$} & \multicolumn{2}{|c|}{$\begin{array}{c}\text { If I do, I understand, } \\
\text { but if I understand } \\
{[\ldots]}\end{array}$} & \multicolumn{2}{|c|}{$\begin{array}{l}\text { Formally, training } \\
\text { the mind freely }\end{array}$} & \multicolumn{2}{|c|}{$\begin{array}{c}\text { Specific Learning } \\
\text { Disabilities: you } \\
\text { never stop learning }\end{array}$} & \multicolumn{2}{|c|}{$\begin{array}{l}\text { Inclusion: the value } \\
\text { of the difference }\end{array}$} \\
\hline & $\%$ & $\#$ & $\%$ & $\#$ & $\%$ & \# & $\%$ & \# & $\%$ & \# \\
\hline from home & 94 & 626 & 95 & 545 & 94 & 497 & 93 & 528 & 96 & 717 \\
\hline from school & 4 & 25 & 3 & 15 & 4 & 23 & 4 & 25 & 2 & 16 \\
\hline public place- & & & & & & & & & & \\
\hline indoors & 0 & 3 & 1 & 4 & 0 & 1 & 1 & 3 & 1 & 5 \\
\hline public place - & & & & & & & & & & \\
\hline outdoors & 0 & 0 & 0 & 0 & 0 & 2 & 0 & 0 & 0 & 0 \\
\hline while travelling & 0 & 2 & 0 & 2 & 0 & 2 & 1 & 3 & 0 & 2 \\
\hline Other & 2 & 13 & 1 & 6 & 1 & 5 & 1 & 7 & 1 & 7 \\
\hline $\begin{array}{l}\text { On a fixed device } \\
\text { (computer) }\end{array}$ & 70 & 465 & 70 & 400 & 69 & 365 & 72 & 406 & 72 & 536 \\
\hline $\begin{array}{l}\text { On a mobile device } \\
\text { (smartphone, } \\
\text { tablet) }\end{array}$ & 17 & 116 & 19 & 111 & 19 & 103 & 17 & 94 & 19 & 141 \\
\hline $\begin{array}{l}\text { on fixed and mobile } \\
\text { devices }\end{array}$ & 13 & 88 & 11 & 61 & 12 & 62 & 12 & 66 & 9 & 70 \\
\hline
\end{tabular}


Table 12 - Evaluation of the courses $(V M=$ very much; $M=$ much; $F=$ fairly; $L=$ little; $V L=$ very little)

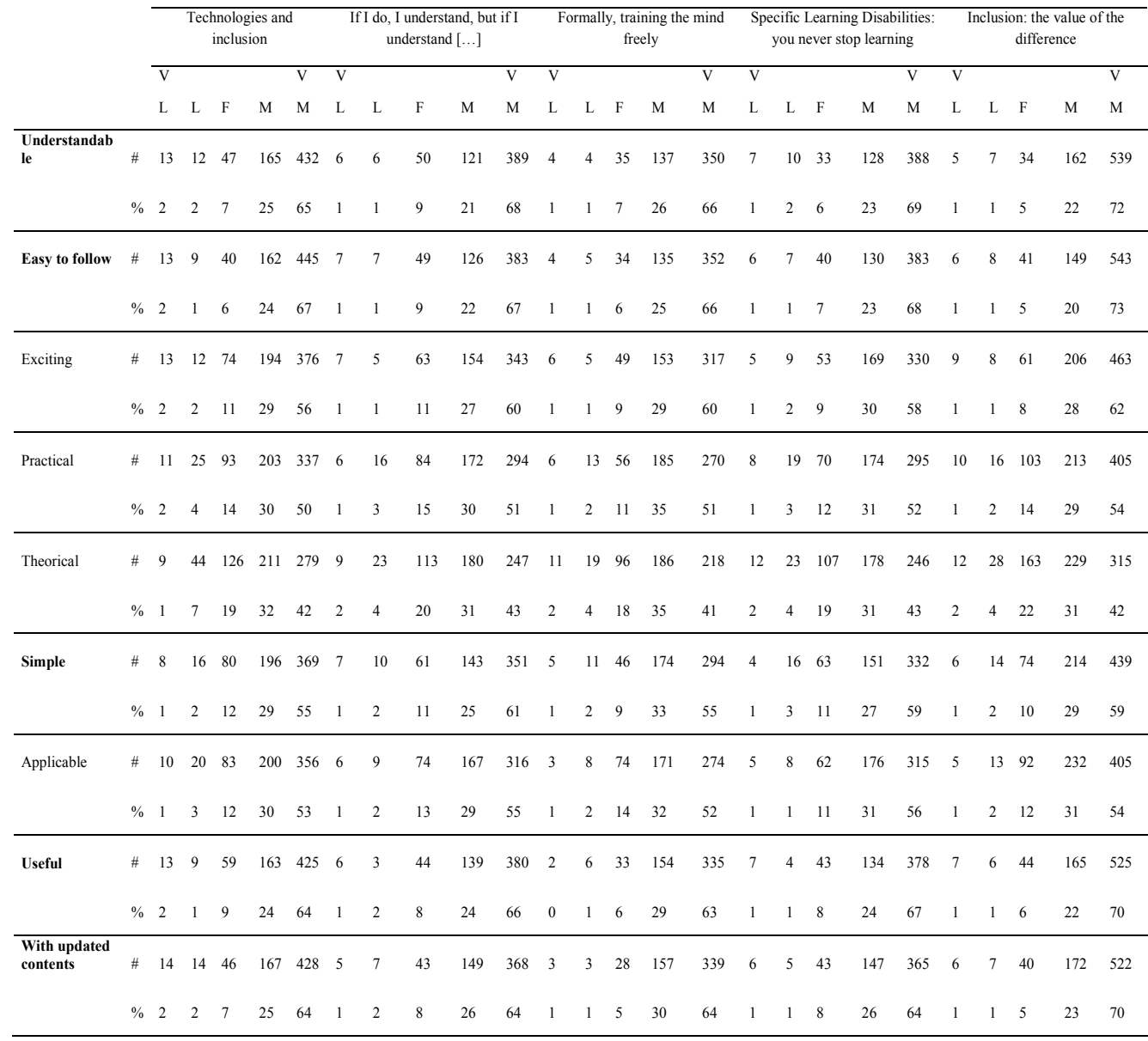


Table 13 - Evaluation of the speakers/experts

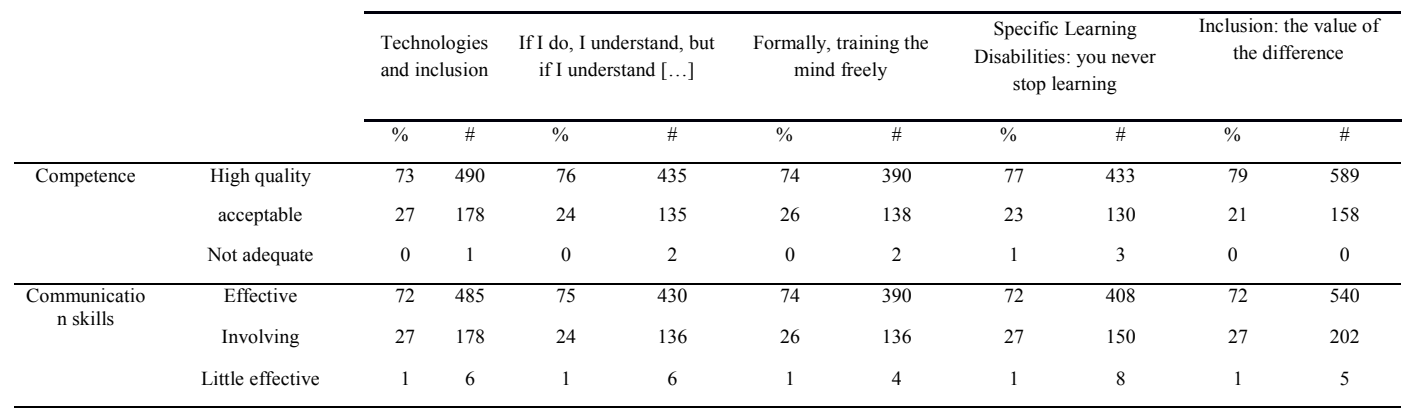


Table 14. Expectations, achievement of the prefixed purposes, consequences in the teaching practice, advisable of courses

\begin{tabular}{|c|c|c|c|c|c|c|c|c|c|c|c|}
\hline & & & & & & & & & & \multirow{2}{*}{\multicolumn{2}{|c|}{$\begin{array}{l}\text { Inclusion: the value of } \\
\text { the difference }\end{array}$}} \\
\hline & & \multicolumn{2}{|c|}{$\begin{array}{l}\text { Technologies and } \\
\text { inclusion }\end{array}$} & \multicolumn{2}{|c|}{$\begin{array}{l}\text { If I do, I understand, } \\
\text { but if I understand [...] }\end{array}$} & \multicolumn{2}{|c|}{$\begin{array}{l}\text { Formally, training the } \\
\text { mind freely }\end{array}$} & \multicolumn{2}{|c|}{$\begin{array}{l}\text { Specific Learning } \\
\text { Disabilities: you never } \\
\text { stop learning }\end{array}$} & & \\
\hline & & $\%$ & \# & $\%$ & \# & $\%$ & $\#$ & $\%$ & \# & $\%$ & $\#$ \\
\hline \multirow{3}{*}{$\begin{array}{l}\text { Responded to the } \\
\text { expectations }\end{array}$} & Yes & 86 & 576 & 90 & 512 & 88 & 469 & 89 & 502 & 88 & 658 \\
\hline & No & 0 & 0 & 0 & 1 & 0 & 2 & 0 & 1 & 0 & 0 \\
\hline & partially & 14 & 93 & 10 & 59 & 11 & 59 & 11 & 63 & 12 & 89 \\
\hline \multirow{3}{*}{$\begin{array}{l}\text { Achievement of } \\
\text { the prefixed } \\
\text { purposes }\end{array}$} & Yes & 85 & 571 & 87 & 500 & 84 & 445 & 88 & 497 & 87 & 651 \\
\hline & No & 0 & 2 & 0 & 2 & 0 & 1 & 0 & 2 & 0 & 1 \\
\hline & partially & 14 & 96 & 12 & 70 & 16 & 84 & 12 & 67 & 13 & 95 \\
\hline \multirow{3}{*}{$\begin{array}{l}\text { Consequences in } \\
\text { the teaching } \\
\text { practice }\end{array}$} & Yes & 68 & 453 & 74 & 426 & 70 & 369 & 73 & 415 & 71 & 529 \\
\hline & No & 2 & 11 & 3 & 16 & 1 & 5 & 3 & 17 & 1 & 10 \\
\hline & partially & 31 & 205 & 23 & 130 & 29 & 156 & 24 & 134 & 28 & 208 \\
\hline \multirow{6}{*}{ Advisable } & $\begin{array}{l}\text { Subject matter } \\
\text { colleagues }\end{array}$ & 32 & 586 & 31 & 473 & 33 & 465 & 32 & 498 & 30 & 643 \\
\hline & $\begin{array}{l}\text { Special } \\
\text { education } \\
\text { colleagues }\end{array}$ & 25 & 447 & 25 & 378 & 23 & 331 & 24 & 376 & 25 & 529 \\
\hline & $\begin{array}{l}\text { New hire } \\
\text { colleagues }\end{array}$ & 15 & 272 & 15 & 229 & 17 & 240 & 16 & 251 & 15 & 320 \\
\hline & $\begin{array}{c}\text { Not-specialized } \\
\text { on special } \\
\text { education } \\
\text { colleagues }\end{array}$ & 11 & 201 & 13 & 197 & 11 & 155 & 12 & 186 & 13 & 281 \\
\hline & $\begin{array}{l}\text { Specialized on } \\
\text { special } \\
\text { education } \\
\text { colleagues }\end{array}$ & 11 & 201 & 11 & 162 & 10 & 135 & 9 & 144 & 11 & 238 \\
\hline & $\begin{array}{c}\text { School } \\
\text { coordinators }\end{array}$ & 6 & 116 & 5 & 8 & 6 & 92 & 6 & 88 & 6 & 137 \\
\hline
\end{tabular}


Table 15. Teachers' motives for following the courses

\begin{tabular}{|c|c|c|c|c|c|c|c|c|c|c|c|}
\hline & & & & & & \multirow{2}{*}{\multicolumn{2}{|c|}{$\begin{array}{l}\text { Formally, training the } \\
\text { mind freely }\end{array}$}} & & & \multirow{2}{*}{\multicolumn{2}{|c|}{$\begin{array}{l}\text { Inclusion: the value } \\
\text { of the difference }\end{array}$}} \\
\hline & & \multicolumn{2}{|c|}{$\begin{array}{l}\text { Technologies and } \\
\text { inclusion }\end{array}$} & \multicolumn{2}{|c|}{$\begin{array}{c}\text { If I do, I understand, } \\
\text { but if I understand } \\
{[\ldots]}\end{array}$} & & & \multicolumn{2}{|c|}{$\begin{array}{l}\text { Specific Learning } \\
\text { Disabilities: you never } \\
\text { stop learning }\end{array}$} & & \\
\hline \multirow{3}{*}{$\begin{array}{l}\text { Inclusion in the } \\
\text { three-year training } \\
\text { plan of the school } \\
\text { institution }\end{array}$} & & $\%$ & \# & $\%$ & $\#$ & $\%$ & $\#$ & $\%$ & \# & $\%$ & \# \\
\hline & Yes & 34 & 229 & 29 & 165 & 30 & 159 & 32 & 183 & 29 & 219 \\
\hline & No & 66 & 440 & 71 & 407 & 70 & 371 & 68 & 383 & 71 & 528 \\
\hline \multirow{3}{*}{$\begin{array}{l}\text { Coherence with the } \\
\text { prioriy identified in } \\
\text { PTOF/RAV/PDM }\end{array}$} & Yes & 53 & 354 & 51 & 290 & 52 & 277 & 51 & 287 & 51 & 383 \\
\hline & No & 17 & 116 & 19 & 106 & 19 & 101 & 18 & 103 & 19 & 139 \\
\hline & partially & 30 & 199 & 31 & 176 & 29 & 152 & 31 & 176 & 30 & 225 \\
\hline \multirow{3}{*}{$\begin{array}{l}\text { Choice of the topic } \\
\text { and discussion } \\
\text { during the meeting } \\
\text { with the school } \\
\text { leader }\end{array}$} & $\begin{array}{l}\text { yes, during faculty } \\
\text { committee with } \\
\text { teachers }\end{array}$ & 11 & 71 & 12 & 71 & 13 & 67 & 11 & 61 & 9 & 70 \\
\hline & $\begin{array}{l}\text { Yes, with school } \\
\text { leader and training } \\
\text { coordinator }\end{array}$ & 6 & 37 & 5 & 30 & 6 & 32 & 7 & 37 & 7 & 54 \\
\hline & $\begin{array}{l}\text { no, I choose the } \\
\text { course independently }\end{array}$ & 84 & 561 & 82 & 471 & 81 & 431 & 83 & 468 & 83 & 623 \\
\hline \multirow{3}{*}{$\begin{array}{l}\text { Choice with free } \\
\text { training and } \\
\text { additional to the } \\
\text { commitments set } \\
\text { forth in the } \\
\text { Institution Plan }\end{array}$} & $\begin{array}{l}\text { Yes, I choose the } \\
\text { course independently } \\
\text { but it is inserted in the } \\
\text { Institutional Plan }\end{array}$ & 22 & 147 & 20 & 116 & 20 & 106 & 20 & 112 & 19 & 142 \\
\hline & $\begin{array}{l}\text { Yes, I choose the } \\
\text { course independently }\end{array}$ & 74 & 494 & 74 & 421 & 75 & 395 & 77 & 433 & 75 & 558 \\
\hline & $\begin{array}{l}\text { No, I am oriented by } \\
\text { school leader and } \\
\text { training coordinator }\end{array}$ & 4 & 28 & 6 & 35 & 5 & 29 & 4 & 21 & 6 & 47 \\
\hline \multirow{6}{*}{ Knowledge mode } & $\begin{array}{l}\text { My colleagues told } \\
\text { me about the course }\end{array}$ & 49 & 359 & 43 & 274 & 48 & 284 & 40 & 248 & 43 & 368 \\
\hline & $\begin{array}{l}\text { has been approved in } \\
\text { the faculty committee }\end{array}$ & 1 & 9 & 2 & 15 & 1 & 8 & 3 & 19 & 2 & 19 \\
\hline & I found it in SOFIA & 20 & 150 & 21 & 135 & 21 & 125 & 18 & 109 & 14 & 118 \\
\hline & $\begin{array}{l}\text { I knew the } \\
\text { Essediquadro platform }\end{array}$ & 20 & 146 & 21 & 132 & 21 & 124 & 23 & 144 & 25 & 209 \\
\hline & $\begin{array}{l}\text { I followed webinars } \\
\text { linked to the course }\end{array}$ & 3 & 22 & 4 & 28 & 3 & 17 & 6 & 35 & 7 & 55 \\
\hline & Other & 7 & 50 & 9 & 55 & 7 & 39 & 11 & 66 & 9 & 77 \\
\hline
\end{tabular}


Table 16 Easy use of the platform

\begin{tabular}{|c|c|c|c|c|c|c|c|c|c|c|}
\hline & \multicolumn{2}{|c|}{$\begin{array}{l}\text { Technologies and } \\
\text { inclusion }\end{array}$} & \multicolumn{2}{|c|}{$\begin{array}{c}\text { If I do, I understand, but if } \\
\text { I understand }[\ldots]\end{array}$} & \multicolumn{2}{|c|}{$\begin{array}{l}\text { Formally, training the mind } \\
\text { freely }\end{array}$} & \multicolumn{2}{|c|}{$\begin{array}{c}\text { Specific Learning } \\
\text { Disabilities: you never stop } \\
\text { learning }\end{array}$} & \multicolumn{2}{|c|}{$\begin{array}{l}\text { Inclusion: the value of the } \\
\text { difference }\end{array}$} \\
\hline & $\%$ & \# & $\%$ & \# & $\%$ & \# & $\%$ & $\#$ & $\%$ & $\#$ \\
\hline Yes & 94 & 628 & 94 & 536 & 95 & 502 & 94 & 534 & 95 & 713 \\
\hline No & 0 & 3 & 0 & 2 & 1 & 4 & 0 & 2 & 0 & 3 \\
\hline partially & 6 & 38 & 6 & 34 & 5 & 24 & 5 & 30 & 4 & 31 \\
\hline
\end{tabular}

